\title{
MIT TANULHATUNK A FEJLŐDÉSELMÉLETEKBŐL A MATEMATIKA TANÍTÁSA SZÁMÁRA?
}

\section{Szerző:}

Pető Ildikó (PhD)

Debreceni Egyetem

Szerző e-mail címe:

peto.ildiko@ped.unideb.hu

\section{Lektorok:}

Németh Nóra Veronika (PhD)

Debreceni Egyetem

Mező Katalin (PhD)

Debreceni Egyetem

...és további két anonim lektor

\begin{abstract}
Absztrakt
Annak ellenére, hogy a gyermekek ösztönösen érdeklődnek a számok és a mennyiség, a mennyiségek közötti relációk, majd a mennyiségek jelölése iránt, az iskolában sok gyerek nem a képességeiből elvárhatóan teljesít vagy éppen kifejezetten nehézséggel küzd a matematika tanulása során. Évek óta kérdés a szakemberek között, hogy mi lehet ennek a magyarázata. Az okok keresése során, ha valóban meg akarjuk találni azokat, majd a megoldást, elkerülhetetlen, hogy visszanyúljunk azokhoz az elméletekhez, amelyek a gyermek fejlődését, a kognitív fejlődést magyarázzák. Jelen írás a legfontosabb elméleteket veszi sorra és tesz kísérletet az összehasonlításukra a számolás tanulására fókuszálva.
\end{abstract}

Kulcsszavak: számolási készségek, kognitív fejlődés

Diszciplinák: gyógypedagógia, pszichológia,

\footnotetext{
Abstract

WHAT CAN WE LEARN FROM THEORIES OF DEVELOPMENTAL PSYCHOLOGY FOR TEACHING MATHEMATICS?

Although children are instinctively interested in numbers and quantities the relationships between quantities, and the marking of numbers, many children in school are not expected to perform well or have a particular difficulty in learning mathematics. For years, there has been a question among professionals as to what may be the reason for this. In the search for causes, if we really want to find the causes and then the solution, it is inevitable that we go back to theories that explain child development,
} 
cognitive development. This paper examines the most important theories and attempts to compare them, focusing on learning to calculate.

Keywords: calculation skills, cognitive development

Disciplines: special education, psychology

Pető Ildikó (2020): Mit tanulhatunk a fejlődéselméletekből a matematika tanítása számára? OxIPO - interdiszciplináris tudományos folyóirat, 2020/2, 33-61.

doi: 10.35405/OXIPO.2020.2.33

A szakemberek között különböző vélemények alakultak ki arról, hogy mi az oka a gyerekek nehézségeinek a matematikában, a matematikával. A legelterjedtebb vélemény a tanárok, szülők és maguk az érintett tanulók között is, hogy a matematika tanulásának képessége genetikailag örökölt tulajdonság. Azt gondolják, hogy ha a szülő kevésbé volt sikeres az iskolai évek alatt matematikából, valószínú, hogy a gyermekük is küzdeni fog vele. Vannak, akik a tanulók gyenge matematikai teljesítményének okaként a tanárokat nevezik meg, akik nem megfelelő módszerekkel oktatnak vagy éppen a szükséges matematikai ismereteik hiányosak (Hill, Rowan és Ball, 2005). Mások viszont úgy vélik, hogy a tanulók problémáit a matematikában bizonyos neurológiai diszfunkciók okozzák (Geary, 2004; Baroody, 2011). Azért hogy világosabban lássuk a gondolatok közötti tényleges hasonlóságokat és különbségeket, érdemes
Összefoglalni a matematika tanulásában fontosnak tűnő összetevőket, folyamatokat és összefüggéseket néhány mértékadó fejlődéselmélet alapján.

\section{A matematika tanulásának összete-} vői, folyamatai és összefüggései a fejlődéselméletekben

A matematika tanulása során jelentkező nehézségeket a szakemberek biológiai, kognitív, szociokulturális és pedagógiai elméletekkel magyarázzák. Az okokat egymásra vetítve láthatjuk, hogy a diákok tanulási nehézségeinek magyarázata változatos, sokoldalú, és összetett. Nyilvánvaló, hogy a tanulók biológiai érettségének változó szintje, a kognitív fejlődés és a számfogalom hiánya hozzájárul a tanulók alacsony teljesítményéhez, de az sem vitatható, hogy a tanárok hiányos matematikai és pedagógiai ismeretei is befolyásolják a tanulók sikerességét. Nem elhanya- 
golható az sem, hogy a tanulók matematikai tanulási nehézségeihez járulnak hozzá a tanulók és a matematika tanulására vonatkozó képességeik társadalmi-kulturális felfogásai.

\section{Magyarázat: biológiai okok}

A szakemberek, pedagógusok és kutatók között vannak, akik szerint a tanulási problémákat az agy biológiai és genetikai hibáiból eredő működési zavarok okozzák, amelyeket részben igazolnak is neurológiai vizsgálatok (Geary, 2007, 2011b; Geary és tsai, 2007). Az ilyen típusú zavarból eredeztethető például a számok közötti megkülönböztetés képességének, a számok nagyságának az azonosítási és az egyszerű mûveletek elvégzésének a gyengesége is (Dehaene, 2003, 2010).

Baroody (2011) és Fox (2001) a biológiai okok kapcsán egy másik feltételezett okról beszél, miszerint a gyerekeknél az érési folyamatok nem azonos ütemben mennek végbe. Ezért történik meg, hogy míg az egyik gyerek már képes a mennyiség-állandóságra, addig a hasonló korú társa nem ismeri fel azt az összefüggést, hogy az elemek száma nem változik attól, hogy az egyes elemek közelebb-távolabb, vízszintesen sorba, körbe rakva vagy rendezetlenül helyezkednek el.

\section{Magyarázat: kognitív okok}

Sok szakember úgy véli, hogy a tanulási problémák oka az, hogy a gyerekek fejletlen kognitív struktúrái fejletlenek (Feuer- stein, 2003; Garner, 2007; Geary, 1995; Montague, 1997). A matematika tanulása szempontjából a gyerekek életkorából elvárhatónál éretlenebb kognitív struktúrák közül, amelyet a tanulók szegényes motiváló tanulási környezete okoz, kiemelt fontosságú az állandóság és a térbeli tájékozódás (a tárgyak, más személyek helyének vagy önmagához viszonyított helyzetének azonosítása, összehasonlítása) képessége (Feuerstein és tsai, 2006; Kamii, Lewis és Kirkland, 2001).

A kognitív struktúrák alapvető, de meghatározó természetéből adódóan a tanárok, a szülők és a tanulók gyakran úgy gondolják, hogy ezek a (kognitív) struktúrák megfelelően működnek, miközben ez nem így történik. A kevésbé fejlett struktúrákkal rendelkező tanulók nem értik, hogy miért nem tudják megtanulni az „újat”, a szülők és a pedagógusok viszont, akik jól fejlett kognitív funkciókkal rendelkeznek, azt nem értik, hogy egy-egy tanuló miért küzd egy olyan fogalom, feladat, ismeret megértésével, ami nyilvánvalónak és egyértelműnek, magától értetődőnek tűnik.

Garner (2007, 2013) és Feuerstein és társai (2006) mint kutatók úgy vélték, hogy a tanulók fejletlen kognitív struktúrája az oka annak, hogy vannak, akik küzdenek a közismereti tárgyakkal.

Egy másik kognitív értelmezés szerint a tanulók mennyiség- és számfogalmának, a korai számolási készségeinek és az általánosítható elvek absztrakciójának a hiánya az az ok, ami jelentősen hozzájárul a tanu- 
lók tanulási nehézségeihez (Bryant, 2005; Geary, 2011b; Jordan és tsai., 2006; Montague, 1997). Vannak, akik azt állították, hogy a számfogalom magában foglalja a kultúrafüggő fogalmak megértését (pl. számnevek, ordinalitás, jelölések stb.). A számfogalom (a számértelmezés képessége) magában foglalja a tanulóknak azon képességeit, hogy különböző mennyiségeket jelenítsenek meg különböző kontextusokban, megértsék a numerikus nagyságrendet, és rugalmasan alkossanak számokat vagy értelmezzék azokat. A tanuló jó szubitizációs képessége (legfeljebb négy tárgy számosságáról alkotott gyors, azonnali és pontos döntést jelen), a megfelelő becslés, számlálás, aritmetikai alapműveletek és a szöveges feladatok helyes megoldása megfelelő mennyiség- és számfogalmat jelez.

Ezek a készségek és fogalmak szerves részét képezik a gyermekek matematikai ismeretszerző képességének, a számok és a műveletek megértésének (Jordan és tsai, 2006; Muldoon és tsai, 2012).

\section{Magyarázat:}

társadalmi, szociális, kulturális okok

A szakemberek egy része a tanulási nehézségeket a tanulók társadalmi-kulturális környezetéből eredeztetik. A gyerekek és a környezetük közötti interakciókat a szülők, a tanárok, a kortársak és a megfelelő közösségek adják és határozzák meg, mely interakciók a jellegükből adódóan a társadalmi, a szociális, a kulturális hatások je- lentősen formálják a tanulók matematikai tanulási készségét is (lásd: Vygotsky, 1978/1930; Clements és Samara, 2007; Feuerstein és tsai, 2006; Kozulin, 2002;). Vizsgálatokból ismert, hogy például a középosztálybeli csoportokhoz viszonyítva az alacsony jövedelmû családok gyermekei gyakran nem rendelkeznek a számok logikai matematikai fogalmával (Kamii, Rummelsburg, és Kari, 2005), amelyek lehetővé teszik a gyermekek számára, hogy konkrét objektumokat elvont fogalmakhoz kössenek, mint például a puzzledarabokból a teljes kép összeállítását vagy az „öt” elem azonosítását (pl. a dominó kockán). Nem kétséges, hogy a matematikában létező összefüggések a tanulók mentális konstrukcióit, logikai matematikai ismereteit igénylik.

A logikai matematikai ismeretek létfontosságúak, mivel az iskolába lépő gyerekek formális matematikai oktatása intézményes formában itt kezdődik el. Azonban ezeknek az ismereteknek a hiánya idézheti elő a matematika tanulásának a sikertelenségét, ami gyakran tanulási zavarrá alakul át. Ha a tanulók tanulási hiányosságait nem kezelik, a sikertelenségeik és a rövidebb távú lemaradásaik miatt nem tudnak majd hosszú távon sem megfelelően haladni a matematikában.

A társadalmi-szociális-kulturális tényezők hozzájárulnak a tanulók tanulási környezetének minőségéhez, amibe beletartozik negatív esetben a hiányosságokra koncentráló szemléletmód és a szélesebb társadalmi környezet alacsony elvárásai 
adott gyermekcsoporttal szemben. Például a hátrányos helyzetú, alacsony szocioökonómiai környezetben élő tanulók helyzetét, előrehaladását befolyásolja az olyan sztereotípia, ami szerint ezek a gyerekek ugyan képesek tanulni, de önálló tanulásra nem képesek (Baroody, 2011; Haberman, 1991).

$\mathrm{Az}$ alacsony társadalmi-gazdasági körülmények között élő tanulók számára nyújtott oktatás gyakran csak a tartalom memorizálására, a memorizálás képességére korlátozódnak. A negatív szociokulturális háttérrel kapcsolatos hiedelmek, elvárások és oktatási gyakorlatok miatt a tanulók az oktatás „áldozataivá” válnak, és (meg)akadályozzák a tanulók tényleges tanulási lehetőségeit, a lehetôségeknek a valósággá válását (Baroody, 2011; Haberman, 1991; Silver és Stein, 1996).

Természetesen az iskolák és osztályok társadalmi, szociokulturális tanulási környezete befolyásolja a tanulók teljesítményét. Az iskolai tantervek határozzák meg a tanulók ismereteit (a tanulás/oktatás tartalmát) és azt, hogy milyen mértékben és minőségben tanulják meg ezeket az ismereteket, amely folyamatban fontos szereplők a tanároknak.

Meghatározó lehet a matematikatanárok szakmai felkészültsége, illetve az adott tanulókról és képességeikről alkotott felfogásuk, hiszen ezekkel (szakmai ismeretek) és az attitűdjük szűrőjén keresztül motiválnak, teremtik meg a lehetőségeket vagy éppen állítanak korlátokat a tanítványaik elé.

\section{Magyarázat: pedagógiai (oktatási) okok}

Akár a szociokulturális okok egyikének is tekinthetnénk a pedagógiai okokat, hiszen a pedagógusképzés és a tantervek, az oktatás keretei az adott társadalmat tükrözik vissza. Azonban érdemes külön is végiggondolni, mert ami a tanórákon történik, az társadalmilag gerjesztett folyamat, aminek a hatása „végleges” és messze mutató. Ezért fontos újra és újra hangsúlyozni, hogy a gyerekek tanulási nehézségeit befolyásolja, de akár eredményezi is a tanárok hiányos matematikai szakmai ismeretei, az elavult vagy nem megfelelő oktatási gyakorlatuk. Az iskolák történelmi és kulturális intézmények, ahol a tanárok gyakran ugyanazt az oktatási módszert alkalmazzák, amit ők maguk tapasztaltak iskoláskorukban (Baroody, 2011; Hill, Rowan és Ball, 2005). Azok a tanárok, akik gyerekként a matematikát a szabályok, tények és eljárások memorizálásával tanulták, hajlamosak ezt a példát, formát és módszert követni a saját tanítványaik tanítása során is (Hiebert, Morris és Glass, 2003; Philipp és tsai, 2007). A módszertani minta mellett ugyanolyan erős hatásúnak tűnik a pedagógusoknak a matematikáról, mint tanulmányi területről alkotott felfogásuk és a matematikai ismereteik. Hill, Rowan és Ball (2005) a matematikai ismereteket úgy írta le mint azt a tudást, amit a tanárok a matematika oktatása során használnak. Ez a tudás magában foglalja az oktatásban általában és adott körülmények között rejlő erőforrás- 
ok hatékony felhasználását, a fogalmak és a folyamatok ábrázolására szolgáló matematikai reprezentációkat, és azt is, hogy figyelembe veszik-e és felhasználják-e a tanulók ötleteit. A tanároknak nemcsak a matematikát (mint tudományt, a tartalmat) kell tudniuk, de pontos, általuk érthetővé tett matematikai szókincs használatát is.

\section{A kognitív képességek}

és a klasszikus fejlődéselméletek: a

számolás és a matematikai ismeretek fejlődése

A tanulók matematikai teljesítményének javítása érdekében elengedhetetlen, hogy megértsük, hogyan tanulnak a kisgyermekek, hogyan tanulják és értik meg a matematikát, hogyan fejlődnek a számolási készségeik. Érdemes áttekinteni három meghatározó tanuláselméletet a számolás folyamatára, a matematikára koncentrálva:

- Jean Piaget konstruktivista,

- Lev Szemjonovics Vigotszkij szocio-konstruktivista,

- Jerome Bruner reprezentációs tanuláselméletét.

\section{Piaget konstruktivista tanuláselmélete}

Az oktatás 1921 és 1951 között túlnyomórészt arra a viselkedéselméleti tanuláselméletre támaszkodott, ami szerint a gyermekek tanulását és viselkedését büntetéssel és jutalmazással lehet irányítani.
Piaget (1896-1980) azonban, aki a tudás eredetét tanulmányozta, megkérdőjelezte a korát meghatározó viselkedéselméletet.

Piaget (1964) úgy vélte, hogy a tanulás a genetikán, a biológiai érésen és a neurológiai fejlődésen alapul. Úgy gondolta, hogy a gyermekek tájékozottak és képesek új ismeretek felépítésére az ismert fogalmaknak (létező sémáknak) az új elemekhez való kapcsolásával, amely gondolattal Piaget a konstruktivizmus elméletének egyik úttörője lett.

Piaget a fejlődést és a tanulást, mint biológiai (érésközpontú) vagy a környezet által meghatározott (tanulásközpontú) folyamat értelmezése helyett a természetesen érő képességek és a környezetével kialakított kapcsolatának kölcsönhatását hangsúlyozta. Piaget fejlődéslélektani munkássága sokirányú, de elméletének három alapvető vonása vált ismertté: a tudás, a gondolkodás keletkezésére és természetére; a fejlődés stádiumaira; és az értelem múveleti struktúráira vonatkozó elgondolások. Elmélete szerint a kognitív képességek alapjai a primitív reflexsémák, amelyek cselekvéses tapasztalatokból kiindulva jutnak el a felnőttkorra jellemző formáig, miközben a gyermek a folyamatnak nem passzív elszenvedője, hanem aktív résztvevője (Kiss 1992, 1995).

A gyermeket Piaget mint érdeklődő „tudóst” írja le, aki kísérletezik, mindent kipróbál, érdeklődik, miközben alkalmazkodik az állandóan változó külső és belső környezethez, amiben az asszimiláció és az akkomodáció, két, egymást kiegészítő 
mechanizmus segíti. Az asszimiláció révén a gyermek tapasztalata beépül a már meglévő ismeretszintbe, a sémába, amit a legjobban a játékukban figyelhetünk meg. $\mathrm{Ha}$ a régi séma erre nem alkalmas, akkor módosítani fogja, vagyis akkomodációt hajt végre, azaz a viselkedését a külső mintához igazítja. A már meglévő, addig használt sémát átalakítja az új helyzetnek megfelelően, miközben tágítja az ismereteit a világról. Az egyensúlyt a környezet valamilyen változása vagy a gyermek érése borítja fel, amire maga a két rendszer úgy reagál, hogy igyekszik megteremteni ismét az egyensúlyt, mely folyamat közben a gyermek tanul, magasabb szintre lép, s az újraszerveződő egyensúly már egy magasabb szintű ismeretszinten történik (Kiss 1992, 1995; Piaget és Inhelder, 1967). A két mechanizmus közötti egyensúly és az egyensúly felborulása váltogatja egymást.

A konstruktivizmus feltételezte, hogy a gyermekek fizikai, társadalmi és logikai matematikai ismereteket igényelnek és szereznek meg ahhoz, hogy az új ötleteiket „támogassák”. Mivel a kisgyermekek kölcsönhatásba kerülnek a környezetükben lévő tárgyakkal, észreveszik azoknak a fizikai természetét, például a piros labda alakját, méretét és színét. Maga a „piros” szín és a „labda” név társadalmi konstrukció, aminek megtanulása absztrakció eredménye. Ahhoz, hogy megértsük az absztrakciót, hogy pl. nem minden gömb alakú tárgy „piros labda”, logikai matematikai ismeretekre van szükség.
A logikai-matematikai tudás egyidejű, egymással összefüggő érzékszervi, mentális és fogalmi műveletekből áll. Piaget szerint (1964) ezek az érzékelő (szenzoros) műveletek (avagy kognitív struktúrák) a tudás megszerzésének alapját képezik és teszik lehetôvé a valódi absztrakciók éretlen vagy pontatlan felfogásának a korrekcióját.

A tanulók a már fentebb említett két alapvető mentális folyamatot, az asszimilációt és az akkomodációt használják a saját megismerési szintjük építésére és fejlesztésére. Az asszimiláció akkor következik be, amikor az új információ erôsen korrelál a meglévő tudással és közel van a megértés. Az asszimilációhoz, ami során a tanulók mentális szerkezetei strukturálisan változatlanok maradnak (Piaget, 1964, 1978, 1993), az összehasonlítás (mint gondolkodási művelet), a mintakeresés és a szabályok felismerése szükséges (Mink, 1964; Sinclair és Kamii, 1970).

A Piaget (1964, 1978) által értelmezett másik mentális folyamat az akkomodáció (alkalmazkodás), ami akkor következik be, amikor a tanulók tapasztalatai vagy élményei ismeretlen vagy meglepő eredményeket hoznak. Ilyen helyzet például, amikor először találkoznak az ábécé betûivel úgy, hogy a betűk ismeretlen értéket képviselnek (pl. a matematikában az a, b, c, x vagy y), ami gyakran a mentális mechanizmusok egyensúlyának a felborulásához vezet. Az a, x vagy y ábrázolása kognitív disszonanciát, feszültséget vált ki, mert a kisiskolások a betűhöz hangot, a betûk együt- 
teséhez pedig szavakat kötnek, nem pedig matematikai jelentést. Annak érdekében, hogy a betű egy ismeretlen értéket képviselhessen, a tanulóknak újra kell ,szervezniük" az addigi ismereteiket. Az ismeretek újraszervezéséhez a meglévő kognitív struktúrák „újrakonfigurálása” szükséges, mivel az alkalmazkodás folyamata során új neurológiai kapcsolatok épülnek ki, amely kapcsolatok („,csomópontok”) lehetővé teszik az új idegrendszeri útvonalak kialakítását. (Ifenthaler, Masduki és Seel, 2011). Mind az asszimiláció, mind az akkomodáció, illetve a két mechanizmus közötti ciklikus mozgás fontos szerepet játszó kognitív folyamat, a tanulók kognitív struktúráinak és megismerési szintjének fejlődésében, a kognitív struktúra megszilárdításban (Bruner, 1964).

Piaget úgy vélte, hogy a tanulók megismerő tevékenysége az idegrendszer fejlődésétől, a fizikai érettségtől és az érzékszerveik fejlődésétől függ (Feuerstein és tsai., 2006). Következtetései a munkájában a kognitív fejlődés négyes szakaszolásához vezetett: 1 . Szenzomotoros szakasz; 2. Műveletek előtti szakasz; 3. Konkrét műveleti szakasz; 4. Formális műveleti szakasz.

Piaget magyarázata szerint a szakaszok egymást folyamatosan felváltják, minden következő szakasz magasabb kognitív szintet tesz lehetővé a gyermek számára; a gyermek adott fejlődési szakaszában alakuló kognitív struktúrák a következő fejlődési szakasz kognitív struktúrájának részévé válnak. Például a kisgyermekek a szenzomotoros szakaszban gyakran támaszkodnak a vizuális és kinesztéziás/taktilis megfigyelésekre. Ahogy a gyermekek egyre többféle tárggyal egyre többet manipulálnak, a kognitív képességeik szintje emelkedik. A fizikai világ további megtapasztalása és a logikaimatematikai tapasztalatok megszerzésének útján a „szenzomotoros szintről” a konkrét műveleti szintet előkészítő „műveletek előtti szakaszba” lépjenek a gyermekek, hogy később képesek legyenek aktívan összekapcsolni a konkrét objektumokat az absztrakt koncepciókkal. A „konkrét mentális műveletek” elengedhetetlenek a tanulók kognitív struktúráinak kialakulásához és a fejlődés legmagasabb kognitív szintjének, a „formális műveleteknek" az eléréséhez. A meglévő struktúrák új struktúrákat hoznak létre, amelyek mindig fejlődnek, és az alacsonyabb struktúrák ily módon is szabályozzák, befolyásolják a magasabb struktúrákat (Piaget, 1964, 1978, 1993).

\section{Vigotszkij szocio-konstruktivista tanuláselmélete}

Jean Piaget kortársaihoz hasonlóan Lev Szemjonovics Vigotszkij (1896-1934) is a tanulás növekedési és fejlődési modelljét hirdette. Vigotszkij is úgy vélte, hogy az emberi kogníciót az egyén genetikája és érése határozza meg, amelyekre hatással vannak a biológiai és/vagy a környezeti hatások is. 
Piaget és Vigotszkij filozófiai nézetei azonban abban különböztek, hogy hogyan történik a tanulás. Vigotszkij úgy vélte, hogy az emberi gondolkodást a gyermekkori társadalmi interakciós tapasztalatok nagymértékben befolyásolják. Úgy vélte, azzal, hogy a gyermekek egy szükebb és tágabb szociokulturális társadalomnak is részei lesznek, a gyermekek megismerésének szintje a gyermekek kultúrájának történelmi tulajdonságai miatt minôségileg egymástól különböznek, illetve a gyermekek életében folyamatosan változik (Vygotsky 1978/1930), amely gondolattal Vigotszkij a társadalmikonstruktivista tanuláselmélet atyjává vált. Vigotszkij azzal érvelt, hogy az egyén értelmi és társadalmi tevékenysége a kognitív fejlődés alapját képezi. Utóbbi kölcsönhatások során történik, mely a társadalmi kölcsönhatások és a kulturális eszközök (pl. nyelv, jelek és szimbólumok) használata révén a gyermekek intellektusát javítja (Kozulin, 2002; Vygotsky, 1978/1930). Fontos tényező, hogy a társadalmilag közvetített interakciók magukban foglalják azokat a személyeket is, akik kulturális ismereteiket (tudatosan) átadják a gyermekeknek.

Vigotszkij úgy fogalmazott, hogy a tanulás a gondolkodás két síkján történik, először társadalmi síkon, majd ezután kognitív síkon jön létre a tudás (Vygotsky, 1978/1930). Úgy képzelte, hogy egy közvetítő személy, pl. a tanár átadja a kulturális információkat és ismereteket a gyermeknek, amelyek a tudás kialakulását eredményezik az egyén tudatában. Az egyén összekapcsolja ezt a két tudásformát, aminek eredménye a fogalmak megértése, amivel a továbbiakban szabályozzák a saját tanulásukat is. Ezek a kognitív cselekvési formák együttesen új és összetett neurológiai útvonalakat generálnak, amelyek erősen összekapcsolódnak, amely útvonalakat Vigotszkij kognitív struktúráknak nevezett. Vigotszkij szerint az olyan biológiai eredetű kognitív struktúrák, mint az észlelés, a memória, a figyelem, az összehasonlító gondolkodás a tanuláshoz szükséges szervezett, bonyolult kognitív rendszereknek tekinthetőek (Kozulin, 2002; Vygotsky, 1965).

Vigotszkij (1978/1930) úgy fogalmazott, hogy a nyelv, a jelek és szimbólumok, beleértve a gyermek belső beszédét is, nélkülözhetetlen eszközök a gyermekek kognitív fejlődéséhez a matematikában is. Vigotszkij gondolatai közül legjobban talán a zóna-elmélete vált ismertté, amivel kapcsolatban bevezette a „proximális (legközelebbi) fejlődési zóna” (,zone of proximal development", ZPD) kifejezést (1. ábra).

Az elmélet szerint a tanítás akkor hatékony, ha a tanuló aktuális fejlettségi szintjét megelőzi, de nem annyira, hogy az a tanuló számára már érthetetlen. Az elgondolást legjobban elképzelni talán egy körkörös ábra alapján lehet. Az egyén a körkörös helyzet, ismeretekkel teli „tér” közepén helyezkedik el, egy olyan sávban, ahol olyan „tudások” vannak, amelyek mindegyikét tudja, ismeri, meg tudja csi- 
1. ábra. Vigotszkij proximális (legköz̧elebbi) fejlödési zóna (,Zone of Proximal Development”ZPD) elélete. (Forrás: Boross, 2014; a szerző kiegészitésével)

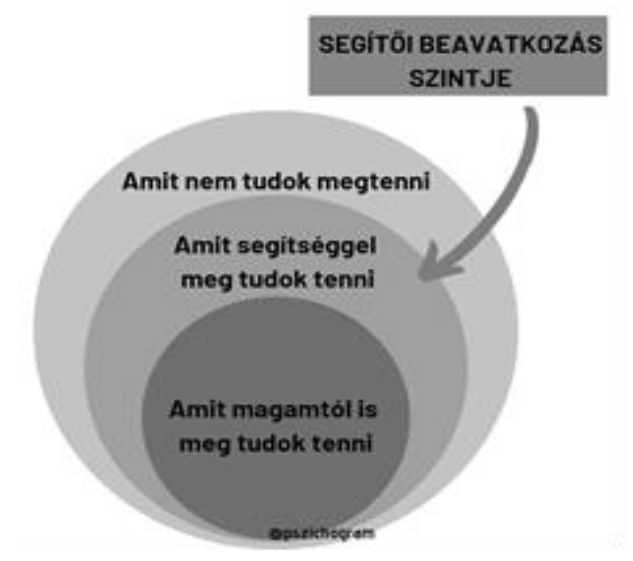

nálni, amiket addigi életében elsajátított. Ezzel a körsávval érintkezik kívülről a „közeli zóna” (ZPD), amiben olyan dolgok vannak, amiket még nem tud, de már érti, amit segítséggel meg tud csinálni. Az elmélet szerint a tanítás akkor hatékony, ha a tanuló aktuális fejlettségi szintjét megelőzi, de nem annyira, hogy az a tanuló számára már érthetetlen. Az elgondolást legjobban elképzelni talán egy körkörös ábra alapján lehet. Az egyén a körkörös helyzet, ismeretekkel teli „tér” közepén helyezkedik el, egy olyan sávban, ahol olyan „tudások” vannak, amelyek mindegyikét tudja, ismeri, meg tudja csinálni, amiket addigi életében elsajátított. Ezzel a körsávval érintkezik kívülről a „,közeli zóna” (ZPD), amiben olyan dolgok vannak, amiket még nem tud, de már érti, amit se- gítséggel meg tud csinálni. A saját zónájából már látja az új ismereteket, de még segítségre szorul, ha azokat szeretné használni. Ezen a zónán túl van az a sáv, ami csupa olyat tartalmaz, amit nem is ért, és nem is tud megcsinálni még segítséggel sem, amelyekről talán még nem is tud, hogy léteznek.

A zónák (sávok) közötti határ, így a szélességük állandóan változik. A belső kör(ök) folyamatosan tágul(nak), bekerülnek a tapasztalatok, az újabb tudás, amivel párhuzamosan a külső sáv szűkülhet. Valójában nem szűkül, mert a külső zóna távolabbi részéből átkerülnek, az egyénhez közelebb kerülnek újabb és újabb ismeretek.

A zónák között annál intenzívebb a mozgás, minél inkább van segítségünk, és 
a segítség minél hozzáértőbb. Vigotszkij elméletének elterjedése óta kiderült annak hiányossága is, amely hiányosság azonban fontos és meghatározó az ismeretszerzés, a tanulás folyamatában és a személyiségfejlődésében.

A legbelső zónában, ahonnan az egyén „rálát” az ismeretekre, az a tudása is benne van, amit önmagáról tud, az énképe, beleértve azt, hogy miről gondolja azt, hogy egyszer meg tudja majd csinálni, vagy azt, hogy soha nem lesz képes rá.

Ennek a tudásnak a kialakulásában (tartalmában) fontos szerepe van a környezete személyeinek. Ha van valaki, aki elhiteti vele, hogy nem képes valamit megcsinálni, akkor egész területek maradhatnak a legkülső sávban. Ha azt mondják neki, hogy a dolog nehéz, de megtanulható, és erre ő is képes, csak küzdeni kell, akkor a területek közötti határvonalak (zónahatárok) áthatolhatóak, a határok rugalmasak és átjárhatóak lesznek az egyén számára is (Smith, s.a.).

A „hiány” különösen fontossá válik a tanulás, az iskolai tanulási folyamatban való részvétel értelmezésében. A tanuláshoz érdeklődés, hit, önbizalom szükséges, amit csak akkor érzünk, ha olyan tudás birtokában vagyunk, amivel kapcsolódni lehet a következő szinthez, és nem ijeszt el a tanulás során mutatkozó sikertelenség, nehézség. A tudás tágulása, gazdagodása nélkül (is) unatkozunk, ha be vagyunk zárva abba a körbe, ahol azok a dolgok vannak, amiket már tudunk, de összezavarodunk, ha a legkülső körbe tar- tozó, a képességeinket (még) meghaladó feladatokat kell megoldanunk.

A ,zónaelmélet” hatása számos, utat talált az iskoláról, a tanításról való gondolkodásban is, ami jól kimutatható a nyolcvanas években terjedő szemléletmódban.

Az irányzat nagy hangsúlyt helyezett a tanulás társas kontextusára, és a kontextus, a helyzet, a társas közeg, a közvetítő felnőtt szerepének értelmezésére, amihez Vigotszkij munkái megfelelő keretet kínáltak. Ugyanakkor a matematika tanítását a hétköznapok problémáival szorosabban összekapcsoló irányzat (realisztikus matematikai modellezés) is egyik forrásának tekinti Vigotszkij gondolatait (Smith, é.n.).

Vigotszkij (1978/1930) hangsúlyozta a tájékozottabb, fejlettebb személyek irányító szerepét az egyént körülvevő, különböző tartalmú zónák dinamikus változásában. A tanárok segíthetik a tanulók önismeretét és önbizalmát a saját kognitív képességeikkel kapcsolatban azzal, hogy a matematikai ismereteket, a tapasztalatszerzésüket a tanítványaik legközelebbi fejlődési zónájához (ZPD-jéhez) igazítják.

A tanároknak nem kell várniuk a gyerekek biológiai érésére, hiszen a tanulók ismeretszerzése, fejlődése támogatható a kihívásokkal teli feladatokkal. A tanárok új reprezentációkat hozhatnak létre, miközben elősegíthetik és fenntarthatják a kommunikációt az osztály tagjai és az osztály és önmaga között.

A társadalmi-konstruktivizmus azt sugallja, hogy a kulturális és a társadalmi 
eredetű eszközökkel (nyelv, jelek és szimbólumok) való tanulás a tanulókat a kognitív gondolkodás magasabb szintjei felé mozdítja el.

\section{Bruner reprezentációs tanuláselmélete}

Jerome Bruner (1915-2016) gondolkodását erősen befolyásolta Piaget konstruktivista és Vigotszkij társadalmi-konstruktivista elmélete. Azt állította, hogy a gyermekek kognitív fejlődése a fizikai és biológiai érettségtől, valamint a természeti és társadalmi-kulturális környezetétől függ. Bruner úgy vélte, hogy amikor egy gyerek belép egy kultúrába, a kultúra is belép a gyermek tudatába, egyszerűbben fogalmazva, az ismereteibe, a tudásába (Bruner, 1964, 1997, 2008; Takaya, 2008).

Bruner (1997) számára az osztályterem fontos közös hely a gyermekek megismeréséhez. Azt állította, hogy a szociálisan elfogadó osztályterem elősegíti a társadalmi elfogadottságot, lehetôvé téve a tanulók számára, hogy kulturális ismereteket szerezzenek. A tanulók részvétele, elfogadása és a társadalmi-kulturális környezeten belüli kölcsönhatás kritikus tényező az önismeret, énkép, a metakogníció és a reflektív gondolkodási folyamatok fejlesztésében.

Bruner egyetértett Piaget-val, hogy a tanulók előzetes ismereteiket felhasználva új koncepciókat és értelmezéseket készítenek egy fogalomról. Sőt, úgy gondolta, hogy az ismeretszerzésben egy koncepció, összefüggés megértése értékesebb és fon- tosabb, mint a konkrét tudás megszerzése. A koncepció „megszerzése” lehetővé teszi a tanulók számára, hogy a saját kognitív struktúrájuk révén az ismereteket felhasználható tudássá alakítsák át. Kognitív fejlődési modellje, a reprezentációs tanuláselmélete azt hangsúlyozza, hogy a tanulóknak a következő reprezentációs formákat kell felépíteniük és érteniük, amelyek egy-egy „síkot” is jelentenek: enaktívak (cselekvéses), ikonikus (belső képalkotás) és szimbolikus (szimbolikusverbális kódolás) saját kognitív struktúráik fejlesztése és létrehozása érdekében (Bruner 1964, 1997).

Fejlődési modelljének első módja vagy fázisa az enaktív (materiális) reprezentáció síkja. Az információk fizikai kódolásához a gyerekek az érzékeiket, teljes testüket, fizikai valójukat használják a környezetük feltárására, a tárgyakkal való manipulálásra (Bruner, 1964). Amikor a kisgyerekek, majd kisiskolások először találkoznak a matematikai problémákkal, a matematika eszközeinek, például kockák, pálcikák, korongok, az ujjaik stratégiai felhasználása segíti őket abban, hogy az elvont fogalmakat mint például a számlálást, a matematikai tulajdonságokat és a múveleteket értelmezzék és megértsék.

Bruner a második kognitív fejlődési szakaszt ikonikus/képi reprezentációnak nevezte, ami akkor alakul ki, amikor a tanulók a meglévő tudásukat a mentális képek segítségével sajátítják el vagy mutatják meg. A képi reprezentációk a múltbeli találkozások és események emlékeiből 
származnak, és térbeli, időbeli és mennyiségi orientációkat tartalmaznak. A numerikus nagyságrendek, a matematikai modellek, az ábrázolási formák mentális képei gyakran tükrözik a tanulók észlelését, értelmezését és a memóriában meglévő tapasztalatok újraértelmezését. A mentális ikonikus képek (vagy vizualizációk) fontos ismeretelméleti eszközök minden tanuló számára, különösen a matematika tanulása során (Bruner, 1964, 2008); Presmeg, 2014).

A Bruner-i harmadik fejlődési szintet a szimbolikus reprezentációs sík jelenti, ami diagramokat, képeket, rajzokat, grafikonokat és hasonlókat tartalmaz. De nyilvánvalóan a szimbolikus reprezentációk minden formában kapcsolódnak a nyelvhez, beleértve a zenei és matematikai jelöléseket, az absztrakt ábrázolásokat, a kulturális innovációk összes termékét is. Az absztrakt reprezentatív formák használatával kapcsolatos ötletek és fogalmak kifejezése magasabb szintű ismereteket igényel. Például a nyelv kognitív eszközként való internalizálása lehetôvé teszi a tanulók számára, hogy rugalmasan használják és átalakítsák át a korábbi „tapasztalatok” új szimbolikus formává. Az „öt” ábrázolható az ujjakkal egy kézen, öt szirommal egy virágon, öt kiscsibével a fészekben, öt körrel vagy az 5-ös számjeggyel, s mindezek verbalizálhatók, aminek alapján Bruner úgy gondolta, hogy a kulturálisan indukált szimbolikus tapasztalatok fejlesztik a tanulók érzékelését és a tanulók nyelvi fejlettségét is (Bruner, 1964, 1997).
Bruner (2008) azt állította, hogy az absztrakció szintjétől függetlenül minden fogalom egyszerű, felismerhető formákban ábrázolható, amelyeket minden tanuló értelmezhet és megért. A tanárok hatékonyan megkönnyít(het)ik a tanulók számára az új fogalmak elsajátítását, figyelembe véve a matematikai reprezentációk ,gazdaságosságát” és „erejét”, attól függően, hogy a tanulók hol tartanak a matematikai tanulmányaikban. Az „economy of a representation” (a reprezentáció gazdaságossága) azt jelenti, hogy a tanulóknak mennyi információra van szükségük ahhoz, hogy a reprezentáció feldolgozására és értelmezésére fókuszáljanak.

A reprezentáció „ereje” (power of the representation) a tanulók kognitív képességeire vonatkozik, arra, hogy a reprezentációt arra használják, hogy összekapcsolják azzal, amit már a konkrét matematikai fogalmakról tudnak.

\section{A kortárs tanulási teoretikusok elméleteinek az összehasonlítása}

Piaget, Vigotszkij és Bruner kiterjedt munkája és felbecsülhetetlen értékei sokkal több és nagyobb, mint ezek a fenti rövid bemutatások. A három teoretikus egyértelműen jelezte a kognitív struktúrák létezését, munkájukban konkrét kognitív folyamatokat és oktatási gyakorlatokat írnak le a tanulók ismeretszerzésével kapcsolatban.

Piaget konstruktivista elmélete szerint a gazdag tanulási tapasztalatok segítik a ta- 
nulókat az új fogalmak és gondolatok megértésében, azoknak a beépülésében, amely folyamatban a tanulók a meglévő kognitív struktúráikkal dolgozzák fel az újabb információkat. Ezzel ellentétben Vigotszkij (1978/1930) szocio-konstruktivista elmélete azt sugallja, hogy a tanulást, pontosabban annak eredményét, a tudást, társadalmi eszközökkel lehet elérni. Vigotszkij úgy vélte, a tanulók először szociális síkon, majd egyedi síkon építik fel a gondolatokat, a tudást. A matematikai órák tele vannak olyan nyelvi elemekkel, jelekkel, szimbólumokkal és eszközökkel, amelyek társadalmi vonatkozásait, tartalmát be kell vezetni és értelmezni, majd használni kell. Miközben a pedagógusok matematikai reprezentációkat és motiváló kérdéseket vetnek fel, a gyerekek egyedül építhetik fel a saját gondolataikat a nyelv, a memória, a figyelem és az öszszehasonlító gondolkodás (már) meglévő kognitív struktúráinak felhasználásával. Ezután a gyerekek megtanulják, hogyan kommunikálhatnak a matematika ,nyelvén" a matematikával, hogyan kerülhetnek kapcsolatba (kommunikálhatnak) a matematikán keresztül másokkal, és mutathatják meg a saját matematikai ötleteiket. Bruner (1964) reprezentációs tanuláselmélete a Vigotszkij által hangsúlyozott kulturális jelekhez és szimbólumokhoz kapcsolódik. A tanulók meglévő kognitív struktúráihoz igazodó, ikonikus és szimbolikus ábrázolások használata ösztönzi a tanulók új fogalmainak és az információknak az asszimilációját a meglévő rend- szerbe (Bruner, 1997). Bruner és Vigotszkij tehát azt állította, hogy a pedagógusnak nem kell megvárnia a gyermekek biológiai érését, ahogy azt Piaget (1964) modellje leírja, hanem a séma elméletre (Bruner) és a ZPD-elméletre (Vigotszkij) hivatkozva azt gondolták, hogy a tanulók kognitív készségeit hatékonyan elő lehet készíteni és fejleszteni a matematika tanulása során (is).

\section{Kognitív képességek a kortárs fejlődéselméletekben: a számolás és a matematikai ismeretek fejlődése}

\section{Geary evolúciós tanuláselmélete}

David Geary (1957- ) fejlődéspszichológus szerint, az emberi kogníciót és a fejlődést az öröklött biológiai tényezők és a szándékos (átgondolt, célzott) társadalmikulturális tapasztalatok befolyásolják. Geary (1995) evolúciós tanuláselmélete Vigotszkij és Bruner elméleteire támaszkodik a tanulók kognitív múködésének eredetéhez viszonyítva. Tanuláselmélete a kognitív ismeretstruktúrák két fajtáját különbözteti meg. Az ismeretek egyike a biológiailag elsődleges tudás, ami megtalálható minden emberi kultúrában, sőt számos különböző állatfajnál is. Az emberek (és az állatok) öröklik a közös, de specifikus kognitív struktúrákat, amelyek növelik esélyeiket a túlélésre, lehetővé téve számukra, hogy alkalmazkodjanak az életkörülményeikhez (Geary, 1995, 2007; Keil, 1981; Sweller, 2008). 
A biológiailag elsődleges struktúrák igen fejlett, speciális neurobiológiai rendszerekből állnak, amelyek a tartományspecifikus információkat dolgozzák fel. Például a perceptuális és a kognitív figyelmi struktúrák, mint pl. a vizuális észlelés-érzékelés, és a szubitizálás (jelentése a matematikában: maximum négy tárgy számosságáról alkotott gyors és pontos döntés) lehetővé teszi az egyénnek, hogy megfigyeljék a környezetük geometriai és kvantitatív jellemzőit. Már a 18 hónaposnál fiatalabb csecsemőknél megfigyelték az „érzékenységet” a három és négy elem közötti ordinális (egymást követő sorrendi) kapcsolat érzékelésére. Az emberi faj számára az egymás utáni sorrendiség, a szubitizáció és az egyszerű aritmetikai műveletekre való képesség alapvető fontosságú volt a faj fennmaradásához (Geary, 1995, 2011a). Ezek a mentális struktúrák segítették pl. a közeledő veszélyes állatok számának vagy a gyüjtendő bogyók szükséges mennyiségének az azonosítását.

Más, öröklött biológiailag elsődleges struktúráknak része a környezetben való tájékozódás képessége, a téri emlékezet (valaminek a helyére), a tárgyak eszközként való használata és a nyelvi készségek. A kutatások arra utalnak, hogy a fejlődő embrió érzékeny lesz az anya kulturális nyelvének a konstrukciójára, mivel az emberi magzat a fejlődése során megtanulja az édesanyja hangját, a környezetnek a magzat által is érzékelhető, illetve a méhben, az anya testében lévő hangmintákat
(Geary, 1995; 2007). Ezt követően a biológiailag elsődleges kognitív struktúrák elengedhetetlenek és alapvetőek a nyelv, a szimbólumok és a matematika komplex kompetenciáinak megszerzéséhez (Jordan és tsai, 2006). Ugyanezek a struktúrák részt vesznek a komplex kognitív feldolgozásban, lehetővé téve a gyermekek számára, hogy gyorsan és könnyedén felfedezzék, megszerezzék, feldolgozzák, asszimilálják az információkat, hogy hatalmas mennyiségü információt sajátítsanak el.

A magasabb szintû megismeréshez Geary (1995, 2007) szerint a másodlagos ismeretek, ellentétben az elsődleges tudással, kultúrafüggőek, azaz eltérőek lehetnek térben és időben. A másodlagos ismeretstruktúrákat az egyén fejlődését támogató társadalmi-kulturális eszközök fejlesztik. Vigotszkij szocio-konstruktivizmusához igazodva, másodlagos struktúrák alakulnak ki a biológiailag kialakult struktúrák és a fejlődésüket befolyásoló társadalmi hatások kölcsönhatásából. Geary feltételezte, hogy a gyermekek biológiailag másodlagos kognitív struktúrái (másodlagos ismereteik) a szándékos és tartós utasítások és gyakorlások révén jönnek létre, amelyekkel a másodlagos struktúrák már rendelkeznek.

David Geary (1995) a biológiailag elsődleges és másodlagos ismeretek fogalmát annak értelmezésére vezette be, hogy az intuitív ismeretek hátterében modulok szerveződnek, amelyekre ráépülnek a kulturális jelenségek. Az intuitív ismereteket 
szokás „naiv ismereteknek” vagy „népi ismereteknek" is nevezni, mely elnevezések arra utalnak, hogy olyan tudásról van szó, amelyek nem igényelnek formális oktatást, amelyeket a gyerekek gyorsan és hatékonyan sajátítanak el a környezetükből. Olyan, mintha velünk született tudás lenne, úgy néz ki, mintha a génekbe lenne kódolva, pedig nem, hanem az ismeretek elsajátítását gyors, beépített tanulási mechanizmusok segítik. Jó példa az anyanyelv elsajátítása, pl. a gyerekek rendkívül gyors ütemben tanulják meg az új szavakat, elég egy szó egyszeri vagy kétszeri ismétlése is ahhoz, hogy megtanulják az új hangsort (fonémasorozatot) és egyben a jelentését is. Az intuitív ismeretek másik fontos jellemzője, hogy a környezet segíti a megtanulását. A nyelvet lassabban, jobban intonálva használjuk, amikor kisgyermekhez szólunk, egy mozdulatot jobban láthatóan végzünk, ha mutatjuk valakinek, tárgyak megszámlálása közben használjuk az ujjunkat, miközben lassabban soroljuk a számokat, ha egy kisgyermekkel együtt végezzük.

A kétféle (elsődleges és másodlagos) ismeretet alapvetően a motiváció különbözteti meg. Az elsődleges ismeretek valójában azokat az intuitív ismereteket jelenti, amit a „beépített” motivációk mozgatnak. Ilyen motiváció pl. a játék, az exploráció, a kíváncsiság, a társas helyzetek keresése, melyek mind a fizikai és társas környezet szabályainak a megismerését segítik. A gyerekek biztatás nélkül mennek a homokozóba, ahol tevékenység közben megtanulják a különböző szilárd anyagok tulajdonságait, fejlődik a nagymozgásos és finommozgásos koordinációjuk. A kockákkal való játék során a fizikai tulajdonságok és használatuk ok-okozati kapcsolatát ismerik fel, megtanulják a testeket megkülönböztetni és ügyesedik a mozgáskoordinációjuk. De játék közben a mások közelsége, a másokkal való együttműködés, a mások megfigyelése, utánzása is természetes folyamatként működik.

A másodlagos ismereteket a tudatunk be tudja fogadni, ám az evolúció során nem az adott ismeret (pl. az olvasás betûk és számok olvasása-, az írás -betűk és számok írása-, a geometria) feldolgozására jöttek létre a feldolgozásért felelős modulok. Például a számok olvasása során az agyunkban léteznek olyan, más feladatra kifejlődött agyi rendszereink, amelyek képesek a vizuális alakzatok gyors felismerésére, vagy a fonémák (beszédhangok) feldolgozására. Ezek további rendszerekkel összekapcsolódva és együttmúködve (pl. a mozgásért felelős rendszerekkel) teszik lehetővé a tényleges olvasás vagy írás bonyolult és összetett mechanizmusát. A geometriát úgy tanuljuk meg, hogy annak alapját azok a téri ismeretek adják, amit a geometria, mint tananyag előtt szereztünk születésünktől a szánkba vett öklünkkel, a csörgő vagy egy szalag megragadásával, az építőkockákkal, a golyókkal, a homokozóban, a mászókán, a karácsonyi mézes pogácsa szaggatása és díszítése közben, stb. 
A fiatal tanulók a matematikai ismereteknek a magasabb formáit úgy alakítják ki, hogy figyelik mások számlálási folyamatát, majd maguk is számolják a tárgyakat. A munka- és hosszú távú memóriarendszerek, amelyek biológiailag másodlagos kognitív struktúráknak minősülnek, segítik a gyerekeket abban, hogyan lehet megnevezni a (pl. arab és a római) számokat, megszámolni 4-5 elemnél több elemet, különböző eszközöket használni (pl. abakusz, számegyenes, körző, stb.).

A szakemberek közös véleménye, hogy ha a biológiailag elsődleges vagy másodlagos struktúrák - mint például a munka és a hosszú távú memória - nem fejlettek, akkor a matematika tanulása a tanulók számára kihívást jelent (Feuerstein és tsai, 2006; Garner, 2007; Geary, 1995).

Míg az elsődleges ismeretek elsajátítására léteznek beépített motivációink, addig a másodlagos ismeretek elsajátítása erőfeszítést, saját akaratot igényel, amely különbséget nem szabad elfelejteni vagy figyelmen kívül hagyni az oktatásban. A kisgyerekek úgy bővítik a szókincsüket, hogy nem tesznek erőfeszítéseket érte, míg az iskolásokat, minél magasabb osztályfokon tanulnak, annál inkább, biztatni kell, jutalmat-büntetést kell kilátásba helyezni, stb. ahhoz, hogy megtanulja egy szó jelentését matematikából, fizikából vagy idegen nyelvből. Ennek enyhítésére a másodlagos ismereteket elsődleges ismeretek segítségével kell(ene) tanítani, azaz például valós problémákkal elindítani az ismeretszerzést, vagy az olvasás gyakorlása során a szociális kapcsolatokat feldolgozó rendszereiket megcélozni az olvasmányban leírt történetekkel, eseményekkel, kapcsolati problémákkal (Geary, 1995, 2004, 2007 - lásd: 2. ábra).

\section{2. ábra. Geary - biológiailag elsödleges és másodlagos struktúrák. (forrás: Boross, 2014)}

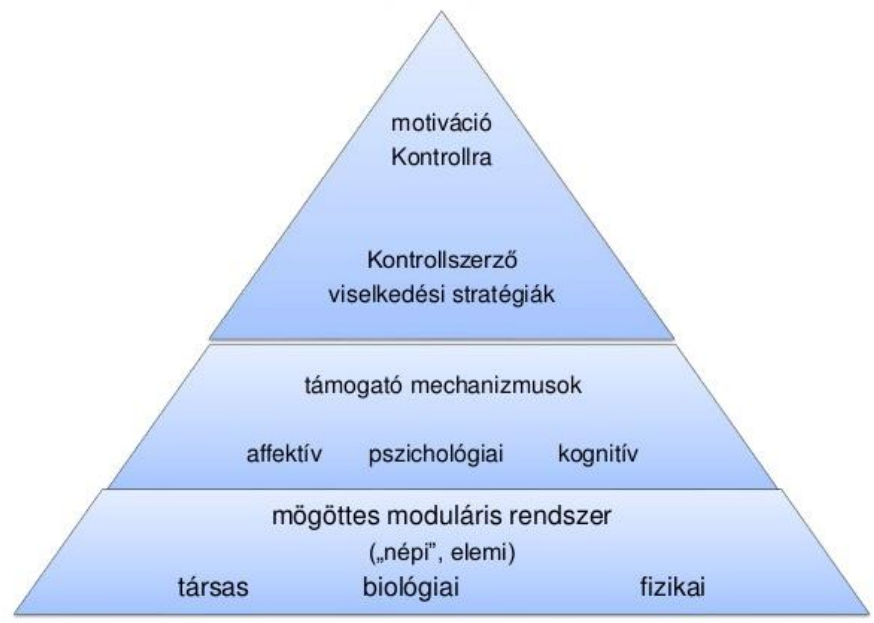




\section{Feuerstein:}

\section{Mediated Learning Experience}

Reuven Feuerstein (1921-1014) fejlödéspszichológiával (is) foglalkozó szakember az emberi elmét módosíthatónak írta le. Úgy vélte, hogy a hozzáértő személyek által teremtett szándékos (célzott, tudatos) helyzetek (tapasztalatszerzési lehetőségek) módosíthatják az egyén neurológiai szerkezetét. Feuerstein „módosíthatóság” fogalma a tanuló azon képességére utal, hogy megváltoztassa az addigi neurológiai állapotát, a mechanizmusokat, függetlenül például a tanulási zavarok okától és körülményeitől (Byrnes és Fox, 1998; Feuerstein és tsai, 2006; Garner, 2007; Kozulin, 2002; Tribus, 1996).

Feuerstein azt állította, hogy a gyermekek intelligenciája az egyének és a környezetük közötti kétféle kölcsönhatás révén formálódik, az ingerekkel való közvetlen érintkezés és a közvetített élményeken keresztül. Az ingerekkel való közvetlen érintkezés a méhben kezdődik, már a magzat (aki ebben az értelemben „tanuló”) módosítja a viselkedését, azért, hogy alkalmazkodjon a külső ingerekhez. Ez a viselkedésbeli változás, alkalmazkodás, aminek során az idegrendszerben új kognitív struktúrák alakulnak ki, ami viszont pozitívan alakítja a tanuló intelligenciáját. Az idősebb gyermekek kognitív fejlődése nagymértékben támaszkodik a hatékony társadalmi-kulturális tapasztalatokra, vagy ahogyan Feuerstein fogalmaz (2006) a „mediált vagy közvetített tanulási tapasztalatra" (mediated learning experiences,
MLE). Vigotszkij (1978/1930) szociokonstruktivista tanulási elméletével összhangban az MLE proaktív módszer arra, hogy „megváltoztassa a tanuló kognitív struktúráját és segítse abban, hogy autonóm, független gondolkodóvá váljon, aki képes ötleteket kezdeményezni és kidolgozni" (Feuerstein és tsai., 2006, 124. o.). A „közvetítő” (szakember, pedagógus, felnőtt környezet) szándéka tehát nem az „akadémiai” ismeretek tanítása, hanem az, hogy a tanuló és a „közvetítő" megértse azt, hogy a tanuló hogyan dolgozza fel az információkat, és aztán olyan módokat, lehetőségeket keressen, amelyek javítják a tanuló feldolgozó képességeit (Tribus, 1996).

Az alapfeltevés tehát az, hogy az ember kognitív struktúrái módosíthatóak, amit mára az idegtudományok vizsgálatokkal bizonyítottak és úgy fogalmaznak, hogy az emberi agyat erős plaszticitás jellemzi. Feuerstein, elmélete a módosíthatóságot hangsúlyozza, amit strukturálisnak tekint, és azt jelenti, hogy nem csak a kognitív és emocionális működés képes bizonyos funkciók vagy tartalmak elvégzésére, hanem közben magában az idegrendszerben is változás történik, a neurotranszmitterek is módosulnak. Ilyen történik akkor, amikor például valamilyen genetikai, organikus, emocionális vagy egyéb trauma miatt ugyan adott agyi területek károsodnak, de azok képesek regenerálódni. A közvetített tanulási tapasztalat („Mediated Learning Experience", a továbbiakban MLE) fontos szerepet játszik ezeknek a változások- 
nak a létrehozásában, mert egy olyan modalitás, ami az emberek közötti lehetséges interakciókat jellemzi. „A humán mediátor (szülő, tanár, testvér vagy kortárs) saját tudatos elhatározásából (intenciójából), a saját maga által megtapasztalt élményeit oly módon közvetíti, hogy azokat a konkrét mediációs helyzetből kiemelve térben és időben szélesebb és mélyebb kontextusba helyezi, valamint megfelelő jelentést és értelmet rendel hozzá, vagyis segíti a fogalmak fejlődését. Az ilyen, tudatosan létrehozott, felépített és kidolgozott interakció váltja ki a módosulást a (mediációban részesülő) egyénben, ezért ezt »lehetséges tanulási potenciálnak« tekintik" (Feuerstein, Falik, Bohács, 2010, 98. o.).

A változás, a módosíthatóság ugyan mindenki számára lehetséges, de a folyamat egyáltalán nem egyértelmű és nem könnyű. Három fő akadályt lehet megnevezni: etiológia (diszfunkció), kritikus kor (az intervenció időpontja és az egyén életkora) és az állapot súlyossága, amitől a módosulás jelentősen függ, azonban egyik sem olyan erős, hogy képes lenne teljesen megakadályozni a változást (esetenként a rehabilitáció folyamatát). Az MLE szisztematikus és kitartó alkalmazása képes létre hozni a változáshoz szükséges feltételeket, azaz a sérült funkciók regenerációját, a megkésett fejlődés serkentését és bizonyos készségek felépítését olyan esetekben is, amelyeket korábban az akadályok miatt képtelennek tartottak a változásra.
Az MLE alkalmazásának és hatékonyságának két fontos eleme a sérült kognitív funkciók és kognitív térkép.

Mindkettő a kiindulópontját jelentik az intervenciónak, azaz a tanulásnak vagy a rehabilitációnak. A mediált szolilokviára szoruló egyének kognitív funkcióproblémáiról (MSL; szolilokvia a belső beszéd monologikus kihangosítását jelenti) írtak, amelyek általában vagy éppen a matematikai tanulás problémáinak a témakörében is értelmezhetőek, öt formában írható le (Feuerstein, Falik, Bohács, 2010, 99. o.): „1) Még ki nem fejlődött kognitív funkciók, amelyeket meg kell jeleníteni a gyermek közvetlen környezetében. 2) Már kifejlődött kognitív funkciók, amelyek azonban még nem manifesztálódtak. 3) Már kifejlődött kognitív funkciók, amelyek azonban a mentális tevékenység egy vagy több szakaszán (bemeneti, feldolgozási, kimeneti) még nem működőképesek. 4) Már kifejlődött kognitív funkciók, amelyek azonban az újdonságuk és/vagy a gyakorlás hiánya miatt még nem stabilak vagy az alkalmazásuk nem megfelelő. 5) Kognitív funkciók, mentális operációk alapvető készségei (beszéd, memória, olvasás stb.), amelyek valamilyen traumatikus agyi sérülés vagy öregedés miatt elvesztek. Ezek a fejlettségi szintek az MLE-n alapuló speciális intervenciós programok révén helyreállíthatóak és rehabilitálhatóak."

A kognitív térkép dimenziói (a feladat tartalma; a feladat megoldásának modalitása; az érintett mentális cselekvés szaka- 
szai; az érintett mentális operációk; a bonyolultság szintje; az absztrakció és a sikeres feladatmegoldás által megkövetelt hatékonyság szintje) mentén lehetséges a feladatok elemzése és kiválasztása a sikeres intervenció érdekében (Feuerstein és tsai, 2006 in: Feuerstein, Falik és Bohács, 2010).

A hatékony MLE magában foglalja: a) a tanuló tudatosságának erősítését azzal kapcsolatban, ő maga hogyan tanul; b) a tanuló kognitív és viselkedési mintáinak a változását; c) a tanuló képességeinek fejlesztését a kapcsolatok és az összefüggések felismerésével és azonosításával kapcsolatban; d) a tanulók eszköztárában a problémák megoldására irányuló stratégiák erôsítését és gazdagítását. Mint ilyen, az MLE szándékos és erôs emberi kölcsönhatásokat igényel a közvetítő és a tanuló között. A közvetítő szándékosan kiválasztja, összeállítja, ütemezi és megszervezi az inger-bemenetet (input), majd mint egy szűrő átalakítja az ingereket, így a tanuló új vagy eltérő módon érzékeli az ingert. Ezek az új felfogások magukban foglalják az inger időbeli, térbeli és sorrendi tulajdonságait, valamint egyéb összefüggéseket, például a jelentés hozzárendelését (Feuerstein és tsai, 2006).
Az MLE folyamat alapvető jellemzője, hogy a mentális feldolgozásnak három szakasza van: a fentebb említett bemenet (input), a kidolgozás és a kimenet (output) (Feuerstein és tsai, 2006). A tanuló az érzékszerveivel az adott számegyenes részleteit érzékeli (input, bemenet), majd a kognitív struktúráival a reprezentációban rejlő figurális egységeket (egységek jelölése, számjegyek) értelmezi, az információkat válogatja, elemzi, osztályozza és szintetizálja (kidolgozás). Miután a szenzoros információt kódolta, a tanuló dönt az információról, majd bemutatja a folyamatnak az eredményét (output). Tehát az érzékszervének a munkája, a kódolási folyamat és az eredeti szenzoros ingerre vonatkozó döntések adják az outputot, de a mentális síkon kialakultakat társadalmikulturális síkon, azaz például beszélgetés során mutatják be. Az input, a kidolgozás és a kimenet mentális folyamatait az alábbi példa segíthet megérteni. A pedagógus egy számegyenest mutat, aminek az a célja, hogy fejlődjön a gyerekeknek a numerikuskapcsolatok megértése (3. ábra), és megkérdezi a tanulókat: „Mit veszel észre? Melyik szám van az ,n’ helyén?”.

3. ábra: „Mit veszel észre? Melyik szám van az, n’ helyén? (Forrás: a Szuerzó)

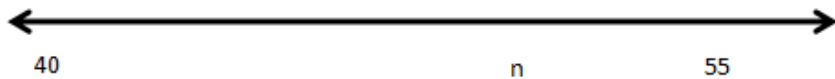


Az $n$ értékét az $n$ térbeli elhelyezkedése alapján lehet megbecsülni, a 40 és az 55 egymáshoz való viszonyából kiindulva. A feladat elvégzésének, azaz a megértésének három feltétele van: 1.) hogy a tanuló tudja, a számegyenes mindkét irányban határozatlan ideig folytatódik; 2.) hogy a számegyenes (jelölése) bármilyen értékkel kezdődhet; 3.) hogy értsék, a 40 és az 55 közötti numerikus értékek között egy egyenletes, arányos skála van.

A tanulók érzékszervi input-ja, hogy észreveszik, az „,n” a 40 és az 55 között helyezkedik el, és körülbelül kétharmad távolságra van a 40-től, hogy az 55-höz van közelebb (bemenet). A kidolgozást jelenti, hogy az „, $n$ " változó ismeretlen értéket képvisel, és hogy „," meghatározható a 40 és 55 közötti távolság egyenlő részekre osztásával. Az output pedig a tanulónak az érték megadásával kapcsolatos ötletei, ami az „,"-re vonatkozó értéket csak közelíti vagy pontosan megadja, valamint ennek az indoklása.

Vigotszkij társadalmi-konstruktivista nézeteivel összhangban Feuerstein és kollégái (2006) szerint a kulturális eredetű jelek és szimbólumok fontos közvetítő eszközök, amelyek ,átadják” a kulturális ismereteket, és megkönnyítik a hallgatók kognitív struktúráinak fejlődését (Kozulin, 2002). A társadalmi tudást közvetítő további eszközök közé tartozik a nyelv, a gesztusok és a viselkedés megfigyelése. Ennek ellenére a nyelv a leghatékonyabb és leggazdaságosabb eszköz az ismeretek és készségek közvetítésére, a jelentést és a megértést szolgálja. Mivel a tanulók közvetített tanulási tapasztalatokat alkalmaznak a kulturálisan előállított jelek, szimbólumok és nyelv használatával, fontos neurológiai változásokat idéznek elő, amely neurológiai változások pedig azt bizonyítják, hogy a tanulás a gyermek idegrendszerében történik (Feuerstein és tsai, 2006).

\section{Garner kognitív struktúra tanuláselmélete}

Betty Garner (1932-) oktatáskutató azt állította, hogy a tanulás akkor következik be, amikor a tanulók „kreatívan kommunikálnak az információval a jelentés megalkotásához" (Garner, 2007, xi.). Összehasonlítva Garner gondolatait Feuerstein MLE elméletével, Garner azt javasolta, hogy a tanulók aktívan vegyenek részt a saját neurológiai struktúráiknak a megváltoztatásában, méghozzá „folyamatos, dinamikus, interaktív tanulási cikluson keresztül" (Garner, 2007, xi). Véleménye szerint sem a matematikai feladatok, sem a tanárok nem képesek a tanulók kognitív struktúráinak a változtatására és a fejlesztésére, csakis a tanulók érhetik el magukban a neurológiai változásokat.

Garner (2007) az elméletét abból építette fel, hogy megfigyelte a tanulókat az ismeretszerzés közben, aminek alapján kiemelte, hogy a tanulók érzékszervi bemeneti tudatossága segíti a megértést, ami a 
tanulók ismeretszintjének a változásához vezet. A kognitív struktúrákat, mint alapvető mentális eszközöket írta le, amelyek nélkülözhetetlenek az információk értelmezéséhez, a világ megismeréséhez. Munkájának központi eleme a kognitív struktúrák hierarchikus rendszerezése, amibe beletartoznak az összehasonlító gondolkodási struktúrák, a szimbolikus ábrázolási struktúrák és logikai érvelési struktúrák, amelyek nélkülözhetetlenek a matematika tanulásához. Minden struktúra tovább tagolódik az általuk támogatott gondolkodásmód szerint, befolyásolva a tanulást, és a megértéshez szükséges alkalmazásokat.

Garner (2007) hierarchikus rendszerének első szintje az összehasonlító gondolkodási struktúrákból áll. Ezek közé tartozik az felismerés/megismerés/azonosítás, az állandóság, a memória, a besorolás, a térbeli és időbeli orientáció, valamint a metaforikus gondolkodás megőrzése. Mindegyik segíti az információk feldolgozását, beleértve az ingerek hasonlóságának és különbözőségének az azonosítását, amelyek feltételei a magasabb rendű kognitív struktúrák és a matematikai összefüggések megértésének fejlesztésének is. Például a matematika fogalmi megértéséhez a tanulóknak fel kell ismerniük a számokat, jeleket és szimbólumokat, meg kell érteniük a közöttük lévő kapcsolatokat és jelentőségüket, valamint azonosítani és generálni számos egyenértékű reprezentációt. A tanulók az állandóság megőrzését használják a műveletek végrehajtása vagy az egyenletek értelmezése során, észreveszik, hogy mi változik, és mi marad változatlan a reprezentációk között. Térbeli tájékozódást alkalmaznak a 10-es számrendszer exponenciális szerkezetének elemzése során, az időbeli tájékozódás pedig lehetővé teszi a tanulók számára, hogy megértsék az algoritmusok és a problémamegoldás egymást követő, lépésenkénti folyamatát. Az összehasonlító gondolkodási struktúrák alapját képezik annak, hogy mindent meg tudjunk tanulni a matematikában.

A Garner-féle (2007) kognitív struktúrák másik eleme a szimbolikus reprezentációs kognitív struktúrákat jelenti. Ez a struktúrarendszer az összehasonlító struktúra adatait absztrakt kódoló rendszerekké alakítja át, így a szimbolikus reprezentáció magába foglalja a nyelv minden (írott és beszélt; a verbális és nonverbális) formáját, a zenét, a ritmust, a mozgással való kifejezéseket, a grafikus formákat (rajzokat, grafikonokat, egyéb matematikai jelenségeket ábrázoló ábrákat, stb.). A számszerūsítéssel pedig lehetôvé válik pl. a két- és háromdimenziós síkok mérése, a geometria, az algebra, a trigonometria, stb. Garner szimbolikus struktúrái egy ikonikus és szimbolikus reprezentációs síkot tükröznek, amelyek nélkülözhetetlenek a matematika absztrakt koncepcióinak megértéséhez és ezeknek a további (fel)használáshoz.

A kognitív strukturák közül Garner szerint a harmadik szint a logikai érvelési struktúrákat tartalmazza. Ezek a struktú- 
rák magukban foglalják a kognitív gondolkodás magasabb szintjeit, lehetővé téve a tanulók számára, hogy „,szisztematikusan feldolgozzák és generálják az információt" (Garner, 2007, 2. o.), illetve a deduktív és az induktív érvelést. A deduktív érveléssel képes az ember következtetéseket levonni a meglévő általánosításokból. Az induktív érvelés lehetővé teszi, hogy megjósoljuk, előre jelezzük és feltételezzük vagy előzetes általánosításokat kapjunk az észlelt mintákból. A logikai gondolkodási struktúrák az ok-okozati összefüggések azonosítását, az elemzési struktúrák a rész-egész közötti látható vagy rejtett kapcsolat felfedezését segíti. A problémafelismerés (a probléma meghatározása) és a problémamegoldás teszi lehetővé a megoldás megtalálása érdekében egy probléma elemei és a paraméterei közötti kapcsolatok felismerését, tisztázását és a megoldás lépéseinek az analizálását.

Ezek a logikai gondolkodási struktúrák nélkülözhetetlen kognitív folyamatok a matematika absztrakcióinak értelmezésében és megértésében, valamint a megfelelő megoldások megtalálásában.

\section{A kortárs tanulási teoretikusok elméleteinek az összehasonlítása}

Geary, Feuerstein és Garner a tanulók tanulási nehézségeinek biológiai, kognitív, szocio-kulturális és pedagógiai eredetével foglalkozott, ami rámutat arra, hogy fontos a tanulók kognitív struktúráinak fejlesztése. Mindegyik szakember a kognitív struktúrákat a tanuláshoz nélkülözhetetlen neurológiai rendszerként írta le. Geary (1995, 2007) úgy vélte, hogy minden gyermek olyan genetikailag öröklött (biológiailag elsődleges) kognitív struktúrákkal születik, amelyek lehetôvé teszik számukra a környezetük értelmezését, megértését és túlélését.

Feuerstein MLE elmélete (2006) megköveteli az oktatási feladatok szándékos (célzott, tudatos) tervezését és az eszközök gondos kiválasztását egy közvetítő által, hogy ösztönözze a tanulók kognitív struktúráinak fejlődését. A mediátor modellezi és verbalizálja a kognitív folyamatokat, amelyeket a hallgatóknak meg kell ismételni. A figyelem összpontosítása, az információcsere, a kérdések megfogalmazása és az érzékelés mindegyike fontos a teljes tanulási folyamatban a közvetítőnek és a tanulónak egyaránt.

Ezzel ellentétben, Garner (2007) a tanulóktól várja, hogy megvizsgáljanak, megfigyeljenek és megoldjanak helyzeteket, problémákat (ami összecseng Piaget konstruktivizmuselméletével). A folyamatban a tanulókat saját reflektív tudatosságuk segíti abban, hogy az új elemeket az előzetes ismereteikhez kapcsolják, pontosabban abba beépítsék.

Alapvetően mindhárom teoretikus azt vallotta, hogy a tanulók kognitív struktúráit kell változtatni, módosítani, fejleszteni a tanuláshoz. Geary (1995) úgy vélte, hogy a genetikailag örökölt struktúrák stimulálása és aktiválása beindítja a magasabb szintű matematika tanulásában kulcsfon- 
tosságú biológiailag másodlagos struktúrákat. Feuerstein és munkatársai (2006) úgy vélték, hogy a közvetítő a saját tudását adja tovább a tanulónak, akinek először szociális síkon kell elsajátítania a fogalmakat és a készségeket, mielőtt megérthetné és egyéni síkon használná őket.

Ezek a gondolatok Vigotszkij (1978/1930) szocio-konstruktivizmus fogalmához illeszkednek.

Piaget konstruktivista elméletéhez hasonlóan Garner (2007) is úgy vélte, hogy a mediációs feladatok, valamint a nyitottabb kérdésfajták használata lehetővé teszi a tanulók számára, hogy gondolkodjanak, használják a meglévő ismereteiket, összehasonlítsanak és összefüggéseket fedezzenek fel, majd új ismeretek alkossanak. Ezek a mentális/kognitív folyamatok megváltoztatják a tanulók kognitív struktúráját alkotó neurológiai szerkezetet, és lehetôvé válik a tudás. Még a tanulók kognitív növekedésének biológiai és fejlődési tényezői mellett is mindhárom tanuláselmélet azt sugallta, hogy a tanulók kognitív struktúráinak fejlesztése pozitívan befolyásolja a tanulók tanulását az élet minden területén, nem csak a matematikában.

Összegzés: mit tanulhatunk a fejlödéselméletekből a matematika tanítása számára?

A matematika tanítása, mint a kognitív struktúrára erősen ható tevékenység és tudományterület mögött húzódó elméle- tek igyekeznek értelmezni a folyamatokat, a tapasztalható fejlődést és problémákat. Sweller (2008) kijelentette, hogy a tanároknak az olyan oktatási gyakorlata, módszerei, amelyek nem veszik figyelembe a tanulók meglévő kognitív struktúráit és fejlődését, valószínúleg nem csak nem hatékonyak, de a fejlődésre veszélyesek is, amivel a tanulással foglalkozó szakemberek, a matematika tanítását kutatók, a neurológusok és a kognitív pszichológusok egyaránt egyetértenek.

A siker érdekében szükséges több és változatosabb feladathelyzetet és ezzel a reprezentációk létrehozásának a lehetőségét megteremteni. Ha ez megtörténik, akkor a diákok megérthetik, hogy a matematika tanulása magas szintű és összetett gondolkodási múveleteket igényel, megoldási stratégiákról, információk összekapcsolásáról és új helyzetekben való alkalmazásáról, önállóságról az alkotásban, tanulásban, alkalmazásban, stb. és ami kiemelten fontos, tanulási közösségről (Bruner, 1964; Garner, 2007; Piaget, 1964; Vygotsky, 1978/1930).

A tanárok által teremtett oktatási helyzetekben el kell távolodni a megszokott módszerektől a problémaközpontú módszerek, a problémahelyzetek, egy produktív környezet felé. A megfelelő kérdések megkövetelik a tanulóktól, hogy felfedezzék és megértsék a matematikai fogalmakat, jelenségeket, összefüggéseket és szintetizálják tudásukat. A nyitott kérdések fókuszálják a hallgatók figyelmét, segítik őket az enaktív (cselekvéses), ikonikus és 
szimbolikus reprezentációkba ágyazott figurális egységek és a matematikai struktúrák elemzésére, megjelenítésére és szintetizálására. A reprezentációk új jellemzői kognitív lehetőségeket teremtettek az absztrakt fogalmak mentális kapcsolatba léptetésére és értelmezésére.

A nemzetközi összehasonlításokban egyre gyengébb tanulói teljesítmény, ezen belül a matematika terén elért eredmények továbbra is kihívást jelentenek hazánk oktatási rendszerének. Az oktatáspolitikusoknak, az oktatáskutatókra és a mindennapokban az iskolákban dolgozó tanárokra támaszkodva, arra kell törekedniük, hogy megállítsák és visszafordítsák a folyamatot, hiszen az iskolások körében mérhető eredmények, amelyek valójában nem a matematikáról, hanem a kognitív képességekről szólnak, nem maradnak az iskolák falai között, hanem munkavállalóként az egész társadalmat érinti. Hatással van és lesz a folyamatosan változó, információs és technológiai fejlődésre, a környezetvédelemre, a gazdaságra, a politikai életre, stb. Tudjuk, hogy a matematikai alapelvek képezik az alapját „,mindennek", amit teszünk, de az alapelvek megértésének és alkalmazásának a feltételei a kognitív funkciók, amelyek dominánsak a matematikában, de különböző mértékben megtalálhatóak minden más területen is.

\section{Irodalom}

Ball, D. L., Hill, H. C., \& Bass, H. (2005). Knowing mathematics for teaching:
Who knows mathematics well enough to teach third grade, and how can we decide? American Educator, 29(1), 1446.

Baroody, A. J. (2011): Blake's Development of the Number Words "One," "Two," and "Three". Cognition and Instruction 29(3), . 265-296. doi: $10.1080 / 07370008.2011 .583370$

Boross, O. (2014): Az iskolai eröszak (basáskodás), a konfliktuskezelés és az evolúció találkozása a boncasztalon. PPKE A Magyar Pszichológiai Társaság XXIII. Országos Tudományos Nagygyúlése 2014. május 15-17, Marosvásárhely. Letöltés: 2019.05.22. Web: https:// www.slideshare.net/OttiliaBoross/bo ncasztalmarosvasarhely2014

Bruner, J. S. (1964). The course of cognitive growth. American Psychologist, 19(1), 1-15. doi:10.1037/h0044160

Bruner, J. S. (1997). Celebrating divergence: Piaget and Vygotsky. Human Development, 40(2), 63-73. doi: $\underline{10.1159 / 000278705}$

Bruner, J. S. (2008). Culture and mind: Their fruitful incommensurability. Ethos, 36(1), 29-45. doi: 10.1111/ j.1548-1352.2008.00002.x

Bryant, D. P. (2005). Commentary on early identification and intervention for students with mathematics difficulties. Journal of Learning Disabilities, 38(4), 340-345. doi: $\underline{10.1177 / 00222194050380041001}$

Byrnes, J. P., és Fox, N. A. (1998). The educational relevance of research in 
cognitive neuroscience. Educational Psychology Review, 10(3), 297-342. doi: 10.1023/A:1022145812276

Clements, D. H., \& Samara, J. (2007). Effects of a preschool mathematics curriculum: Summative research on the Building Blocks project. Journal for Research in Mathematics Education, 38(2), 136-163. doi: $10.2307 / 30034954$

Dehaene, S. (2003): A számérzée. Osiris Kiadó, Budapest

Dehaene, S. (2010). The calculating brain. In D. A. Sousa (Ed.), Mind, brain, \& education: Neuroscience implications for the classroom. Bloomington, Solution Tree Press. 178-198.

Feuerstein, R (2003).: The Theory of Structural Cognitive Modifiability and Mediated Learning Experience. In Feuerstein's Theory and Applied Systems: A Reader. The Feuerstein Institute, Jerusalem: ICELP. 37-45.

Feuerstein, F., Falik, L.H. és Bohács, K. (2010): A közvetített szolilokvia: a nyelv és a kommunikáció mediációja a belső beszéden keresztül. Magyar Pedagógia 110. (2.) 97-118.

Feuerstein, R., Feuerstein, R. S., Falik, L., \& Rand, Y. (2006). Creating and enhancing cognitive modifiability: The Feuerstein instrumental enrichment program. Jerusalem: ICELP

Fox, R. (2001). Constructivism examined. Oxford Review of Education, 27(1), 23 35. doi: $10.1080 / 03054980125310$

Garner, B. K. (2007). Getting to got it!: Helping struggling students learn how to learn. Alexandria, VA: Association for Supervision and Curriculum Development.

Garner, B. K. (2013). The power of noticing. Educational Leadership, 70(5), 48-52.

Geary, D. C. (1995). Reflections of evolution and culture in children's cognition: Implications for mathematical development and instruction. American Psychologist, 50(1), 24-37. doi: 10.1037//0003-066x.50.1.24

Geary, D. C. (2004). Mathematics and learning disabilities. Journal of Learning disabilities, 37(1), 4-15.

Geary, D. C. (2007). Educating the evolved mind: Conceptual foundations for an evolutionary educational psychology. In Carlson, J. S. \& Levin, J. R. (Eds.): Educating the evolved mind. 1-100. Letöltés: 2019.06.14. Web: http://www.researchgate.net/publicati on/242124970_Conceptual_Foundati ons_for_an_Evolutionary_Educationa 1_Psychology

Geary, D. C. (2011a). Consequences, characteristics, and causes of mathematical learning disabilities and persistent low achievement in mathematics. Journal of Developmental Behavioral Pediatrics, 32(3), 250-263. doi: 10.1097/DBP.0b013e318209edef

Geary. D. C. (2011b). Cognitive predictors of achievement growth in mathematics: A 5-year longitudinal study. Developmental Psychology, 47(6), 1539-1552. doi: $10.1037 / \mathrm{a} 0025510$ 
Geary, D. C., Hoard, M. K., Byrd-Craven, J., Nugent, L., \& Numtee, C. (2007). Cognitive mechanisms underlying achievement deficits in children with mathematical learning disability. Child Development, 78(4), 1343-1359. doi: 10.1111/i.1467-8624.2007.01069.x

Haberman, M. (1991). The pedagogy of poverty versus good teaching. Phi Delta Kappa, 73(4), 290-294.

Hiebert, J., Morris, A.K., \& Glass, B. (2003). Learning to learn to teach: An experiment model for teaching and teacher preparation in mathematics. Journal of Mathematics Teacher Education, 6(3), 201-222. doi: 10.1023/A:102516 $\underline{2108648}$

Hill, H. C., Rowan, B., \& Ball, D. L. (2005). Effects of teachers' mathematical knowledge for teaching on student achievement. American Educational Research Journal, 42(2), pp. 371- 406. doi: $\underline{10.3102 / 00028312042002371}$

Ifenthaler, D., Masduki, I., \& Seel, N. M. (2011). The mystery of cognitive structure and how we can detect it: Tracking the development of cognitive structures over time. Instructional Science: An International Journal of the Learning Sciences, 39(1), pp. 41-61. doi: 10.1007/s11251-009-9097-6

Jordan, N. C., Kaplan, D., Olah, L. N., \& Locuniak, M. N. (2006). Number sense growth in kindergarten: A longitudinal investigation of children at risk for mathematics difficulties.
Child Development, 77(1), 153-175. doi: 10.1111/j.1467-8624.2006.00862.x

Kamii, C., Lewis, B. A., \& Kirkland, L. (2001). Manipulatives: When are they useful? The Journal of Mathematical Behavior, 20(1), 21-31. doi: 10.1016/S0732-3123(01)00059-1

Kamii, C., Rummelsburg, J., \& Kari, A. (2005). Teaching arithmetic to lowperforming, low-SES first graders. The Journal of Mathematical Behavior, 24(1), 39-50. doi: 10.1016/j.jmathb.2004. $\underline{12.004}$

Keil, F. C. (1981). Constraints on knowledge and cognitive development. Psychological Review, 88 (3), 197-227. doi: 10.1037/0033295X.88.3.197

Kiss, T. (1992): Piaget a gyermek kauzális gondolkodása kialakulásáról: az oksági gondolkodás fejlesztése aź óvodában. Piaget Alapítvány, Debrecen

Kiss, T. (1995): A gyermekek matematikai gondolkodásának kialakulása 2-7 életévekben: fejlesztésének hatékony módszerei. Piaget Alapítvány, Debrecen.

Kozulin, A. (2002). Sociocultural theory and the mediated learning experience. School Psychology International, 23(1), 7-35. doi: $\underline{10.1177 / 01430343020}$ 23001729

Mink, O. G. (1964). Experience and cognitive structure. Journal of Research in Science Teaching, 2(3), 196-203. doi:10.1002/tea.3660020308

Montague, M. (1997). Cognitive strategy instruction in mathematics for 
students with learning disabilities. Journal of Learning Disabilities, 30(2), 164-177. doi: 10.1177/00222194970 $\underline{3000204}$

Muldoon, K., Towse, J., Simms, V., Perra, O., \& Menzies, V. (2012). A longitudinal analysis of estimation, counting skills, and mathematical ability across the first year of school. Developmental Psychology, 49(2), 250-257. doi: $10.1037 / \mathrm{a} 0028240$

Piaget, J. (1964). Part 1: Cognitive development in children: Piaget development and learning. Journal of Research in Science Teaching, 2(3), 176-186. doi:10.1002/tea.3660020306

Piaget, J (1978): Szimbólumképzés a gyermekekorban: Utánzás, játék és álom: A kép és ábrázolás. Gondolat Kiadó, Budapest.

Piaget, J. (1993): Az értelem pszichológiája. Gondolat Kiadó, Budapest

Piaget, J. és Inhelder, B. (1967): A gyermek logikájától az ifjú logikájáig : A formális múveleti struktúrák kialakulása. Akadémiai Kiadó, Budapest.

Presmeg, N. (2014). Contemplating visualization as an epistemological learning tool in mathematics. ZDM The International Journal on Mathematics Education, 46(1), 151-157. doi: $\underline{1007 / \mathrm{s} 11858-013-0561-\mathrm{Z}}$

Silver, E. A., \& Stein, M. (1996). The Quasar project: The "revolution of the possible" in mathematics instructional reform in urban middle schools. Urban
Education, 30(4), 476-521. doi: $\underline{10.1177 / 0042085996030004006}$

Sinclair, H., \& Kamii, C. (1970). Some applications of Piaget's theory for teaching young children. The School Review, 78(2), 169-183.

Skemp, R. R. (1976/2006). Relational understanding and instrumental understanding. Mathematics Teaching in the Middle School, 12(2), 85-95.

Smith, Frank (é.n.): A tanulás és felejtés könyve. Letöltés: 2019.06.15. Web: http://www.demokratikusneveles.hu/i ndex.php/cikkek/18-frank-mith/196frank-smith-artalomjegyzek?highlight= ytoxmdp7atowo3m6odoidgfudwzdox mio2k6mttzojk6imzlbgvqdmopcyi7ato yo3m6ntoiznjhbmsio2k6mztzoju6innt axroijtpojq7czoxoijhijtpoju7czo3oijrw 7zuexzlijtpojy7czoxmtoiznjhbmsgc21p dggio2k6nztzojezoijmcmfuaybzbwl0ac bhijtpojg7czo3oijzbwl0acbhijtpojk7cz o5oijhigvdtm55dmuio30= és http:// www.demokratikusneveles.hu/index.p hp/cikkek/18-frank-smith/202-franksmith-11-reszlet

Sweller, J. (2008). Instructional implications of David C. Geary's evolutionary educational Psychology. Educational Psychologist, 43(4), 214-216. doi:10.1080/00461520802392208

Takaya, K. (2008). Jerome Bruner's theory of education: From early Bruner to later Bruner. Interchange, 39(1), pp. 1-19. doi: $10.1007 / \mathrm{s} 10780$ 008-9039-2 
Tribus, M. (1996). Quality in education according to the teachings of Deming and Feuerstein. School Psychology International, 17(1), 93-112. doi: $\underline{10.1177 / 0143034396171008}$

Vygotsky, L. S. (1965). Psychology and localization of functions. Neuropsychologia, 3, 381-386.
Vygotsky, L. S. (1978/1930). Mind in society: The development of higher psychological processes (M. Cole, V. John-Steiner, S. Scribner, \& E. Souberman, Eds.). Cambridge, MA: Harvard University Press. Letöltés: 2019.06.14. Web: http://ouleft.org /wp-content/uploads/VygotskyMind-in-Society.pdf 